Volume 3, Issue 1, February 2018, Pages: 245, DOI: http://dx.doi.org/10.19082/ah245

\title{
GENETIC STUDY OF THE SPATIAL ENDOGAMY AND ITS IMPACT ON SOCIAL IMMOBILITY IN THE REGION OF BENI OUARSOUS IN THE TRARAS MOUNTAINS (ALGERIA)
}

\author{
Djamel Belkhatir, amaria Aouar, Hoari Hamdaoui, Zakarya Moqaddem, Sarra Khater, Nafissa Chabni
}

Laboratoire de valorisation de l'action de l'homme pour la protection de l'environnement et application en santé publique (équipe environnement et santé), Faculté des Sciences, Université Abou Bekr Belkaïd de Tlemcen, Algérie djamelbelkhatir@yahoo.fr

\section{TYPE OF ARTICLE: CONFERENCE ABSTRACT}

\begin{abstract}
Background: In a given population, the magnitude and evolution of endogamy and exogamy are good indicators of the distribution, structure and genetic heterogeneity. They are counted among the factors ensuring social immobility and, consequently, the isolation of different genetic combinations. The main objective, therefore, of our study is to determine the geographical endogamy rate in the Beni Ouarsous region (north western Algeria).

Methods: To elucidate the social situation of this practice, a prospective study was conducted on 182 pairs sampled randomly between January and June of 2014. Indeed, based on the survey data, the choice of spouse is treated by geographical origin (place of birth) and locality of residence before and after marriage of both partners in the generation of the studied couples and their parents' generation.

Results: The results revealed high levels of spatial and social immobility endogamy. Compared with other results from different Algerian regions, our results show that the population of Beni Ouarsous is a closed population.

Conclusion: This analysis reveals some major points of the genetic aspect of spatial endogamy and its impact on social immobility in the region of Beni Ouarsous in the Traras Mountains.

KEYWORDS: Spouse choice, Spatial endogamy, Closed population, Beni Ouarsous, Algeria.
\end{abstract}

\footnotetext{
Abstracts of Second International Conference on Health Sciences and Medical Technologies, 10-12 October 2017, Tlemcen, Algeria (ICHSMT-17)

(C) 2018 The Authors. This is an open access article under the terms of the Creative Commons Attribution-NonCommercialNoDerivs License, which permits use and distribution in any medium, provided the original work is properly cited, the use is non-commercial and no modifications or adaptations are made.
} 